\title{
Investigating the Application of Communicative Language Teaching Principles in Primary-Education: A Comparison of CLIL and FL Classrooms
}

\author{
Irene Guzmán-Alcón ${ }^{1}$ \\ ${ }^{1}$ Faculty of Humanities and Social Sciences, Universitat Jaume I, Castelló, Spain \\ Correspondence: Irene Guzmán-Alcón, Faculty of Humanities and Social Sciences, Universitat Jaume I, Castelló, \\ Spain.
}

Received: October 1, 2018 Accepted: January 6, 2019 Online Published: January 9, 2019

doi: $10.5539 /$ elt.v12n2p88 URL: https://doi.org/10.5539/elt.v12n2p88

\begin{abstract}
It is widely accepted that the learning of a new language, among other advantages, promotes respect and interest of the students towards other cultures and languages. The question is how learning languages can be promoted in educational settings. The aim of the present study is to explore the principles of communicative language teaching in primary-education CLIL and FL classrooms. More specifically, in this paper we address to what extent collaborative work, attention to language and content and corrective feedback are observed during teacher-student and peer interaction in these educational settings. Following an action research approach, ten Spanish and ten Maths sessions were observed and recorded. Furthermore, whole group interaction and peer interaction were analysed in relation to the participants' attention to language and content. Results from the study show that communicative language teaching is the approach followed in CLIL and FL sessions, tasks being the organizing units. However, differences are observed in relation to attention to language and use of correction strategies. Our findings suggest the need to use strategies to draw attention to language and content in CLIL settings, and the importance of using a more even range of correction strategies both in CLIL and FL classrooms.
\end{abstract}

Keywords: communicative language teaching, CLIL, task-based language teaching, peer interaction, whole classroom interaction, corrective feedback

\section{Introduction}

The world-wide economic phenomenon of globalization has led to greater interaction between countries, especially in matters of a commercial nature. This means that it is important not only to speak and write, but also to understand another language other than the mother tongue. Due to its status as a lingua franca, that additional language is almost always English. Educators and language professionals must understand that in order to remain competitive and provide an enhanced range of professional opportunities to students, continual improvement in teaching and learning English is a key issue. In addition, as multilingualism is the norm rather than the exception in the world (Cenoz, 2013; Jessner, 2008), multilingual education is encouraged because it is believed to promote respect and interest towards the rest of the world's cultures and languages.

The question is how learning languages can be promoted in Content and Language Integrated Learning (CLIL) and foreign language (FL) classrooms. Earlier research on language teaching methodology highlights a number of different methods and approaches to teach a FL (e.g., Howatt, 1984; Richards \& Rodgers, 1986; Sánchez, 1997). Although, nowadays, there is widespread agreement that there is no single method that guarantees successful FL learning, there seems to be a general consensus that communicative language teaching (CLT) may provide learners with opportunities to engage in task performance, and therefore learn a language by using it. Examples of CLT teaching can be found in task-based language teaching (Ellis, 2009) and, relevant to the current study, in CLIL (Mehisto et al., 2008). However, and in spite of the claimed benefits of CLT, classroom studies are needed to explore how the principles of CLT are applied in intact FL and CLIL classrooms. An issue that the present study aims to address.

\subsection{Communicative Language Teaching, Task Based Learning and CLIL}

CLT is an approach towards language teaching and learning which aims to make use of real-life situations to stimulate language use. In this approach, the student is the protagonist of the teaching-learning process, and the 
teacher becomes a mediator whose function is to guide the student to improve their communicative skills. In CLT teachers must not only take into account communication itself, but attention must also be paid to the sociocultural aspects of communication, such as the setting in which the interaction takes place, the relationship between interlocutors, and the purpose of the conversation. Moreover, this approach seeks to promote fluency rather than focus on grammatical accuracy. According to Brandl (2008), we can describe seven principles of communicative language learning, which are summarized below:

Principle 1: Using tasks as an Organizational Principle. For decades, traditional methods of language teaching have used grammar as the basis for organizing the syllabus. Using CLT methodologies, grammar is no longer the principal focus. In other words, the development of communicative skills is placed at the forefront, and grammar is only used to support language use in situations that simulate real-life interactions.

Principle 2: Promoting Learning by doing. A task-based approach to learning implies the notion of learning by doing. It is based on the theory that a hands-on approach positively enhances learners' cognitive engagement. In addition, the principle of "learning by doing" is strongly supported by an active approach to language use in early learners.

Principle 3: Input needs to be rich. L1 acquisition in natural settings implies a wide range of rich input in numerous contexts and situations over many years. Needless to say, we cannot expect to replicate such rich input in the classroom in order to develop native-like language skills. However, as suggested by Mehisto et al. (2008) and Krashen (1981), input needs to be rich for learners to be more successful. Therefore, students need oral and written input from the teacher, the teaching material, multimedia resources, or from real-life interaction.

Principle 4: Input needs to be meaningful, comprehensible, and elaborate. One essential factor in order for learning to occur is that the information that a learner processes needs to be meaningful. In fact, the information presented must be clearly related to the learner's pre-existing knowledge. It should be emphasized that the knowledge learners already have needs to be organized in such a way that the new information is easily assimilated into their cognitive structure.

Principle 5: Promoting cooperative and collaborative learning. In general education, cooperation and collaboration have long been recognized as strong facilitators of learning. Students work together in small cooperative teams, such as groups or pairs to complete activities. In second language (L2) learning, students also work cooperatively on language-learning tasks, or they even achieve language learning goals collaboratively though communicative use of the target language.

Principle 6: Focusing on form. Students need to combine fluency with accuracy. One of the debates regarding grammar teaching is whether it is more beneficial to make grammar explicit or to have the learners figure out the rules themselves. A focus on forms approach represents a fairly traditional approach to teaching grammar where students spend much of their time learning isolated linguistic structures in a sequence predetermined and imposed by a syllabus designer; in this approach, meaning is often ignored. In contrast, Long (1996) suggested a 'focus on form' approach to grammar teaching. This author emphasizes form-meaning connections and suggests paying attention to grammar though communicative tasks.

Principle 7: Providing corrective feedback. Feedback can be categorized in two ways, positive and negative (Mackey, 2006), and different studies have examined the role of corrective feedback (Alcón-Soler \& García Mayo, 2008; Ellis et al., 2001). On the one hand, positive feedback confirms the accuracy of a student's response. Teachers demonstrate this behaviour by agreeing or showing that they understand. On the other hand, negative feedback is known as error correction and has a corrective function on a student's language behaviour.

Before moving any further, it would be beneficial to define the term 'task', since tasks are the instruments through which learning by doing is promoted. Various definitions of task have been provided in the relevant literature. For instance, Skehan (1996, p. 38) defines a task as "an activity in which meaning is primary; there is some sort of relationship to the real world; task completion has some priority; and the assessment of task performance is in terms of task outcome". In a similar vein, Ellis and Shintani (2013, pp. 135-136) proposed that for an instructional activity to satisfy the criteria of a task it must do the following:

1) The primary focus should be on meaning

2) There should be some kind of 'gap'

3) Learners should largely rely on their own resources

4) There is a clearly defined outcome other than the use of language

Ellis (2003) reviews the benefits of a task-based approach, pointing out that, when performing a task, learners 
are not primarily concerned with using language correctly, but rather with achieving a communicative goal. Additionally, as reported by Alcón-Soler (2018), while completing a task, teachers and students engage in interaction and opportunities for the creation of meaning and language learning are observed. While a task-based approach has been widely used in FL settings, the emergence of CLIL, as a content-based language learning approach, has motivated research in a wide range of educational settings (Dalton-Puffer, 2007; Ruiz de Zarobe \& Jiménez-Catalan, 2009; Cenoz, Genesse, \& Gorter, 2014; García Mayo, 2015; Ruiz de Zarobe, 2013, 2015; Llinares \& Morton, 2017). There seems to be a general consensus on the main characteristics of CLIL settings. They are that: 1) the syllabus is organized around the content; 2) meaningful tasks are performed while content and language are learned; and 3) the methodology follows the principles of CLT. Moreover, in CLIL settings learning by doing is encouraged and the principles of CLT are claimed to be followed. As mentioned above, Brandl (2008) suggests that in a CLT approach tasks are the organizational principle of a lesson. Additionally, the author claims that some of the issues to consider are rich input (which needs to be meaningful, comprehensible, and elaborate), collaborative learning, and recognizing the role of affective factors. The author also suggests focus on form as a principle in CLT. Following Long (1996), the author refers to a focus on form approach as a way of paying attention to grammar though communicative tasks. One way of implementing a focus on form approach in the classroom is by providing feedback during task-based interaction. As language educators we are also aware of the role of corrective feedback during task-performance (see Lyster, 1998; Lyster \& Saito, 2010; Mackey, 2006), and different studies have examined the role of corrective feedback in language classrooms (Alcón-Soler \& García-Mayo, 2008; Ellis et al., 2001; Lyster \& Mori, 2006). However, there seems to be a need for further research exploring the role of feedback, and how learning as a mediated process occurs in CLIL and FL contexts (see Vygotsky, 1978; Lantolf, 2000, for a review of L2 learning as a mediated process).

\subsection{Study Rationale and Research Questions}

Considering the principles of CLT and the positive role of interaction in language learning (for a review, see García-Mayo \& Alcón-Soler, 2013; Mackey, 2007; Pica, 1994, among others), the present study will explore to what extent collaborative work, attention to language and content, corrective feedback, and use of L1 and L2 are observed during task-based interaction in CLIL and FL classrooms in primary education at an international school. In addition, two types of participatory structure will be analysed: whole class (teacher-students) and peer interaction. In this way, the study will provide insights on how language and content learning is approached through communicative tasks in two particular educational settings: CLIL and FL classrooms in primary education at an international school, where it is claimed that students are allowed to link learning to its closest environment and their real-life experiences. With this in mind, the following research questions (RQs) have been formulated to guide the study:

RQ1: Do CLIL and FL classes follow the principals of CLT?

RQ2: Is there any difference between CLIL and FL classroom interaction (teacher-student versus peer interaction) regarding collaborative work, focus on form, corrective feedback, and L1/L2 use?

\section{Method}

The present study follows an action research approach. As suggested by Richards and Nunan (1990), action research is relevant in language education for teaching and research purposes. Therefore, this study may be useful because of its ecological validity, that is to say it is conducted in intact classrooms. Findings from this study will also allow teachers to improve their teaching, and provide researchers with potential issues for further empirical investigations.

\subsection{Setting}

The study was conducted at an international European School located in Oxfordshire, United Kingdom. The school offers a broad and balanced education for 3 to 19 year-olds, and claims to foster a unique multicultural outlook in pupils. Families choose the school because multilingual education is encouraged. In their first year, many pupils become acquainted with a new language and a good foundation is built across the curriculum in order for them to become fluent in at least two of the four languages offered by the school (English, German, French, and Spanish). Students are engaged in multilingual schooling from the age of three. Regarding instructional languages, a multilingual programme is followed, in which teachers give their classes in one language for half a week and in another language the rest of the week. This approach attempts to ensure that the two languages, in this study English and Spanish, are spread evenly. The school can be defined as multilingual because different languages are used in everyday communication with students. One teacher and one teaching assistant are assigned to each class. Additionally, in the case of students with special needs, they are accompanied throughout the day by individualized support staff. 


\subsection{Participants}

The sample consisted of twenty-seven students: $37 \%$ female $(n=10)$ and $63 \%$ male $(n=17)$. All participants were six years old at the time of the study. As the participants were enrolled in a multilingual programme, they received instruction in Spanish for one half of the school week, and in English for the other half. Although all students spoke English at school, just over half of them (55.6\%) did not have English as a mother tongue. Table 1, below, illustrates the distribution of L1s among the sample. In general, the students were considered to have an intermediate level of competence in English. However, three children had an upper-intermediate level, while two others had a level that could best be described as lower-intermediate to elementary.

Table 1. L1 distribution among the sample

\begin{tabular}{ll}
\hline English & $44.4 \%$ \\
\hline Arabic & $7.4 \%$ \\
Spanish & $7.4 \%$ \\
Portuguese & $11.1 \%$ \\
Hungarian & $3.7 \%$ \\
French & $3.7 \%$ \\
Japanese & $3.7 \%$ \\
Serbo-Croatian & $3.7 \%$ \\
Italian & $3.7 \%$ \\
Finnish & $3.7 \%$ \\
Czech & $3.7 \%$ \\
Hindi & $3.7 \%$ \\
\hline
\end{tabular}

\subsection{Data Collection and Analysis}

Data were collected during a total of ten class sessions in which Spanish was the language of instruction: five sessions of Spanish language (FL), and five sessions of Maths taught in Spanish (CLIL). In both classes, students engaged in task performance. For example, counting tens and units to know how much items cost, describing dimensions and shapes in order describe the classroom, describing animals in a farm, and telling the time in relation to their daily schedule. During the sessions observed, the students performed these different tasks in pairs, small groups, or in lockstep (i.e., teacher-student interaction).

Three observation schemes were designed by the researcher. The first observation scheme (see Appendix A) included the principles of communicative language teaching adapted from Brandl (2008). The second and third observation schemes were designed to observe whether there were differences between the FL and CLIL classrooms. Following Ellis and Shintani (2013, p. 143), the second scheme (see Appendix B) was used to observe if peer-interaction facilitated collaborative work, focus on meaning or form, use of L1 and L2, and the provision of feedback in language and content sessions. Additionally, the third scheme (see Appendix C) was used to explore whether whole-class task performance triggered collaborative interaction, attention to meaning, use of L1 and L2, and corrective feedback. During each session, the researcher and the teacher completed the observation schemes individually and after each session, they compared the information included in each observation scheme. Cases of discrepancy were discussed, and an agreement was reached for $93 \%$ of the data.

\section{Results and Discussion}

As mentioned above, to respond to the RQs, observations were made in five sessions of Spanish as a FL and five sessions of maths taught through Spanish (CLIL). In relation to RQ1, which addressed whether language and content classes followed the principals of CLT, we can claim that most of the principles of CLT are observed both in FL and CLIL sessions. Now, we will justify this claim by giving further details of our observations. 
Table 2. Observed principles of CLT

\begin{tabular}{lll}
\hline Principles observed & CLIL & $\boldsymbol{F L}$ \\
\hline Principle 1: Use tasks as an organizational Principle. & $5 / 5$ & $5 / 5$ \\
Principle 2: Promote learning by doing & $5 / 5$ & $5 / 5$ \\
Principle 3: Input needs to be rich. & $5 / 5$ & $5 / 5$ \\
Principle 4: Input needs to be meaningful, comprehensible, and elaborate. & $5 / 5$ & $0 / 5$ \\
Principle 5: Promote cooperative and collaborative learning & $5 / 5$ & $0 / 5$ \\
Principle 6: Focus on form & $0 / 5$ & $5 / 5$ \\
Principle 7: Provide corrective feedback & $0 / 5$ & $5 / 5$ \\
\hline
\end{tabular}

Table 2, above, provides a summary of the findings from both the FL and the CLIL sessions; the fraction $\mathrm{x} / 5$ refers to the number of occurrences of each principle found in the five sessions observed. These findings show that both modalities adhere to the following principles of CLT: promotion of learning by doing, provision of rich input, and lesson organization through tasks. In both modalities, it can be clearly observed that the children learn language and content by means of tasks, and that the teacher has an excellent knowledge of both language and content. As a result, the provision of rich input is observed. However, other principles are not observed in both modalities. For instance, dealing with the use of meaningful tasks (principle 4) was observed in the CLIL sessions, but it was not in the FL sessions. In these sessions, even if students had to perform tasks, the teacher frequently relied on grammar explanations and provided exercises, such as fill in the gaps and copy and repeat sentences. In addition, the principle of cooperative learning (principle 5) was observed in the CLIL sessions, but not in the FL sessions, in which the teacher was in charge of classroom interaction. This is illustrated in the following extracts.

Extract 1: Cooperative learning in CLIL

01 S1: Hoy somos cinco trabajando juntos [Today we five work together]

02 S2: No, somos cuatro [No, we are four]

03 S3: No, somos cinco, un grupo de tres y uno de dos [No, we are five, one group of three and one of two]

04 S1: Bien, tres más dos [Ok, three plus two]

05 S2: Sí, cinco [Yes, five]

Extract 2: Teacher in charge of FL classroom interaction

01 T: Qué tenemos en la foto? [What do we have in this picture]

02 S1: Sí, una... [Yes, one...]

03 T: No, María a ver ayuda a John, que vemos aquí. [No, Maria, please help John, what do we see here]

04 S2: ¡Ah! no lo sé [Oh I don't know]

05 T: Sí, es una oveja [Yes, it is a sheep]

In extract 1, the CLIL students are discussing how to organize the class in groups in order to become familiar with addition. We can see how the students use the FL to negotiate and collaboratively reach a solution regarding the way in which they plan to work together. In contrast, in extract 2, the teacher in the FL class takes charge of the classroom interaction, effectively allocating turns and providing the solution for the students.

Nevertheless, some principles of CLT were not observed in the CLIL sessions. Specifically, focus on form (principle 6) and the provision of corrective feedback (principle 7), both of which were exclusively observed in the FL sessions (see extract 3). In the CLIL sessions, most students engage in doing the tasks with peers and the teacher did not give any feedback regarding their grammar.

Extract 3: Feedback in FL classrooms

01 T: En la granja vimos gallinas... [In the farm we can see chickens]

02 S1: Cabra [a goat]

03 S2: Veo dos vaca [I see two cow] 
04 T: Dos vacas. Una vaca, singular, dos vacas plural, es decir más de una [Two cows. One cow, singular, two cows plural. In other words, more than one]

05 S2: Sí, dos vacas [Yes, two cows]

Extract 4: Feedback in CLIL classrooms

01 S1: Toma dos cubo de diez y yo tengo ya 3 bolas [Take 2 cube of ten and I have already got 3 marbles]

02 S2: Vale, voy (trae el material) [OK, I'll go (he brings the material)]

03 S3: Ahora, tenemos que dibujar el número. [Now, we have to draw the number]

$04 \mathrm{~S} 2$ : Vale, trenta y tres [Ok, thirty three]

05 S1: No, veinte tres [No, twenty three]

06 S3: ¿veinte tres? [Twenty three?]

07 S2: Sí, tenemos dos cubo de diez [Yes, we have got 2 cubes of ten]

08 S1: Vale, otro cubo y tenemos 33 [Ok, another cube and we have 33]

If we compare extract 3 and 4 we can see differences in relation to corrective feedback. In FL classrooms, the teacher points out grammar errors and explicitly explains the difference between singular and plural (extract 3 , line 04), while in CLIL classrooms students focus on task completion, and they do not pay attention to language. This is illustrated when the students say dos cubo de diez (extract 4, lines 01 and 07); they have made a mistake with the plural noun, but nobody points it out.

To sum up, in the findings related to RQ1, there seems to be differences between FL and CLIL sessions in relation to the way in which they adhere to the principles of CLT. While in the CLIL sessions meaningful input is observed and grammar is only used to support task performance, in the FL sessions the teacher relies on exercises designed to practice discrete language items, rather than allowing students to use their own linguistic resources during task performance. Another interesting difference can be observed in relation to one specific affective factor that has the potential to strongly influence language learning; namely, anxiety. Anxiety seems to manifest itself in the CLIL sessions, since students reported feeling stressed or nervous, however this was not observed or reported by students during the FL sessions. One possible explanation is that teachers' personality may play a role; an issue which would benefit from additional exploration in future action research studies. Findings related to RQ1 also seem to suggest that Brandl's (2008) principles are flexible and they are likely to change according to the language learning context being CLIL or FL. This issue has implications for teachers. As language teachers we need to be aware of the principles of CLT, how they can be applied in different language learning contexts, and try to find the best teaching techniques to increase opportunities for input (Krashen, 1981), output (Alcón-Soler \& García-Mayo, 2008), and feedback (Mackey, 2006) in FL and CLIL classrooms.

In relation to RQ2, which explores the differences between FL and CLIL classroom interaction (teacher-student vs peer interaction), differences can be observed regarding attention to language and meaning, use of L2, and feedback.

Table 3. Teacher- students interaction in FL and CLIL sessions

\begin{tabular}{lll}
\hline Items observed & $\boldsymbol{C L I L}$ & $\boldsymbol{F L}$ \\
\hline Scaffold learners' participation & $2 / 5$ & $3 / 5$ \\
Orientate learners to focus on meaning & $5 / 5$ & $0 / 5$ \\
Orientate learners to focus on form & $0 / 5$ & $5 / 5$ \\
$\mathbf{L} 1$ to support the learner comprehension & $5 / 5$ & $0 / 5$ \\
Encourage learners to use of the $\mathbf{L} 2$ & $0 / 5$ & $5 / 5$ \\
Give clear feedback to learners & $0 / 5$ & $5 / 5$ \\
\hline
\end{tabular}

Table 3, above, shows to what extent we were able to observe how the teacher uses the principles of CLT during teacher-students interaction to scaffold participation, to draw learners' their attention to language and content, encourage use of L1/L2, and the provision of feedback in FL and CLIL sessions. Our observation of the teacher's supportive role during task performance in FL and CLIL sessions points to the following. In the CLIL sessions 
the teacher did not pay much attention to language, most of the content-specific words were translated to English to facilitate understanding. Moreover, there was very little feedback or attention to grammar. In contrast, in the FL class, the teacher consistently corrected the students and pointed out new words. Furthermore, if the students did not know how to say something in Spanish, they were not allowed to translate into English. In this sense, they were encouraged to paraphrase the meaning in Spanish.

As regards peer interaction, differences can also be observed between the FL and the CLIL sessions as can be seen in Table 4. During peer interaction, in the CLIL sessions, students frequently focus on task demands, for instance, solving a problem, rather than paying attention to the language itself. In contrast, in the FL class students frequently try to find the appropriate words in the language of instruction, while they carry out a meaningful task. For instance, when they were describing a farm that they visited on a school trip they focused on the description of the animals and tried to say the verb correctly.

Table 4. Peer interaction in FL and CLIL sessions

\begin{tabular}{lll}
\hline Items Observed & $\boldsymbol{C L I L}$ & $\boldsymbol{F L}$ \\
\hline Learners' collaborative work & $5 / 5$ & $0 / 5$ \\
Focus on meaning & $5 / 5$ & $0 / 5$ \\
Focus on form & $0 / 5$ & $5 / 5$ \\
Use of L1 & $5 / 5$ & $0 / 5$ \\
Use of L2 & $0 / 5$ & $5 / 5$ \\
Assist each other with feedback & $0 / 5$ & $5 / 5$ \\
\hline
\end{tabular}

Moreover, it was observed that the students in the CLIL sessions work collaboratively, assisting each other with linguistic problems as and when they arise, but this type of peer-interaction did not occur in the FL sessions. One possible explanation for this is that, in the CLIL sessions, knowledge is co-constructed through interaction during task-based performance (Vygotsky, 1978; Lantolf, 2000). The question is why learners do not collaboratively construct knowledge during task-based interaction in the FL sessions. One possible explanation for this is that in these sessions tasks are ignored in order to favour exercises which focus on language; this triggers individual as opposed to cooperative work.

Differences could also be observed in relation to the types of corrective feedback that were provided in CLIL and FL sessions (Table 5).

Table 5. Types of corrective feedback in CLIL and FL sessions

\begin{tabular}{lll}
\hline Type of feedback & $\boldsymbol{C L I L}$ & $\boldsymbol{F L}$ \\
\hline Metalinguistic clues & $3 \%$ & $31 \%$ \\
Elicitations & $3 \%$ & $30 \%$ \\
Repetitions & $11 \%$ & $14 \%$ \\
Clarifications & $14 \%$ & $15 \%$ \\
Recasts & $69 \%$ & $10 \%$ \\
\hline
\end{tabular}

As can be seen above, in the CLIL sessions, feedback is mainly provided by means of recasts (69\%), and this is followed by clarification questions (14\%). The extracts below provide a typical example of these correction strategies as observed in the classroom discourse:

Extract 5: Meaning oriented recast

01 S: Esto es... [It's a this...]

02 T: Esto es un cuadrado sin vértices [It's a square with no vertices] 


\section{Extract 6: Clarification question}

01 S1: Me gusta la forma de la caja de zapatos [I like the shape of the box of the shoes]

02 T: ¿Qué forma? [Which shape?]

03 S1: Sí, la que te dan en las tiendas cuando compras zapatos [Yes, the one they gave you in the shops when you buy shoes]

$04 \mathrm{~T}$ : ¡Ah!, ¿te refieres a la forma rectangular? [Oh, you mean the rectangle shape?]

05 S1: Sí, la forma rectangular [Yes, the rectangle shape]

In the extract 5 , the teacher takes up the student's utterance and reformulates it by means of a recast. The focus is on meaning; that is, the student used esto es (line 01) to define a square he was pointing to. In this example, the correction strategy provides the student with the possibility of learning vocabulary, cuadrado and vértices (line 02 ), at the same time as providing a focus on content. Similarly, the teacher relies on clarification questions to introduce new vocabulary while the student engages in task performance. In extract 6 , the student cannot think of the correct term and so uses a paraphrase, la caja de zapatos (line 01), to which the teacher responds with clarification requests (lines 02 and 04), the students takes up the cue from the teacher and is able to utter the correct form, la forma rectangular (line 05 ).

Although recasts were a prominent correction strategy with a focus on meaning, they were also used in the CLIL sessions as a means to integrate language and content, as the following extract attests:

\section{Extract 7: Language/content integration recast}

01 S1: Me gustan el triángulo porque tiene tres vértices] [I like them the triangle because it has three vertices]

$02 \mathrm{~T}$ : ¡Ah!, $\mathrm{O}$ sea que te gusta el triángulo porque tiene tres vértices

$03 \mathbf{y}$ tres lados [Oh, so you like the triangle because it has three vertices and three sides]

04 S1: Bien [Ok]

In extract 7, S1 used me gustan el triángulo (line 01), which, according to the rules of concordance in Spanish, is wrong. The teacher takes up the student's utterance and reformulates it by means of a recast (line 02) and provides additional content information. In this example, the correction strategy provides the student with the possibility of learning vocabulary, tres lados (line 03), at the same time as providing a focus on content

In contrast, in the FL sessions, the most frequently observed correction strategies were use of metalinguistic clues $(31 \%)$ and elicitation techniques $(30 \%)$. These were followed by clarification questions $(15 \%)$, which are frequently language oriented; that is, narrowly focussing on language. The extracts below give an example of each:

\section{Extract 8: Metalinguistic clue}

01 T: Siéntate al lado de Marcos [Sit down next to Marcos]

02 S1: No cabo ahí [I don't fit ((regular)) there]

03 T: No se dice cabo. Se dice quepo. Para referirnos a la primera

04 persona del verbo caber nunca podremos decir cabo. [You say fit. For the first person of the verb fit ((irregular)) you should never say fit ((regular))]

\section{Extract 9: Elicitation}

01 S1: Mira la oreja [Look at the ear]

02 T: ¿La oreja? [The ear?]

03 S1: Sí, en la granja [Yes, in the farm]

04 T: ¿La oreja esta?[This ear? ((Pointing to ear))]

05 S1: No, la oveja [No, the sheep]

$06 \mathrm{~T}$ : $\mathrm{A} \mathrm{Ah} ! \ldots$ te ha quedado muy bien la oveja [Oh!, your sheep looks really good]

\section{Extract 10: Language oriented recast}

01 T: ¿Has encontrado la información? [Did you find the information?]

02 S1: No, la ratón no work [No, the mouse doesn't funciona] 


\section{$03 \mathrm{~T}$ : ¡Ah! el ratón no va [the mouse doesn’t work]}

04 S1: No, no va [No, it doesn't work]

In extract 8 , the student makes an error with an irregular verb, no cabo ahi (line 02), and the teacher explicitly corrects the student, Se dice quepo (line 03), providing the following metalinguistic information, Para referirnos a la primera persona del verbo caber nunca podremos decir cabo (lines 03 and 04).

The use of elicitation is also used as a correction strategy in the FL sessions. In extract 9, the teacher double checks if the student is referring to oreja (line 02) in an attempt to trigger student self-correction. The student does not initially perceive the correction and answers, sí, en la granja (line 03), but, on a further comprehension check by the teacher, self-corrects, no, la oveja (line 05). Finally, the teacher incorporates the word oveja and evaluates the student's picture of the sheep by saying te ha quedado muy bien la oveja (line 06). Finally, in the FL sessions recasts are frequently focused on language or in response to translanguaging. For instance, in extract 10 the student cannot think of the correct term in Spanish and uses the word in English, "work" (line 02), to which the teacher responds with a recast (line 03), and the student responds with the utterance no, no va (line 04), indicating that the teacher's correction has been understood.

In summary, different correction strategies are observed in CLIL and FL sessions. In the CLIL sessions, implicit correction is frequently performed by means of recasts, which can be meaning oriented or combine language and content. This finding is important because, as reported in previous L2 acquisition research (Lyster \& Mori, 2006; Alcón-Soler \& García-Mayo, 2008), orientation of the recast may influence learners' noticing of language. This study shows that both types of recasts occur in the CLIL sessions, further studies should explore the impact of both types of recasts on learning language and content together. In contrast, in the FL sessions, explicit correction by means of metalinguistic clues and elicitation techniques are observed. This may explain why the students primarily take the role of learner in the FL sessions while in the CLIL sessions, although not totally abandoning this role, they function more as communicators. Perhaps, it would be beneficial for both CLIL and FL students if the teacher relies on a more balanced range of strategies. If so learners in both modalities could move more fluidly between the role of learner and that of communicator. We propose that this is an issue in which to raise awareness in both FL and CLIL teachers.

\section{Conclusions, Limitations, and Future Directions}

The aim of this paper has been to analyze how FL and CLIL classes in a multilingual school use tasks and follow the principles of CLT. In addition, it explores whether differences are observed between CLIL and FL classroom interaction, both in teacher-student and peer interaction. Findings from the study show that CLT is the approach followed in a multilingual school setting. It seems that children learn language and content by means of tasks in the CLIL sessions, while tasks are transformed into exercises in the FL sessions. Our findings also show that meaningful tasks and cooperative learning are not observed in FL classrooms, while attention to language and provision of feedback are frequently observed.

The present study is exploratory and descriptive, and data has been collected in an ecologically valid way, providing us with information for further empirical research. One of the issues for further investigation is whether implicit correction provided by means of recasts is noticed by primary students during task performance. Similarly, it would be interesting to explore whether the orientation of recasts (i.e.: language or meaning) may influence learners' noticing of language and content during task performance. Finally, since metalinguistic clues and elicitation techniques are more frequently used than recasts in the FL sessions, in the context of the present study, it would be interesting to explore the impact of each type of feedback on primary students' noticing of language.

Nevertheless, the study is subject to some limitations and care should be taken about generalizing the results. First, the number of participants is limited and the study was conducted in a particular language-learning context. In addition, although in this paper we have not looked at the use of different languages with different functions, translanguaging occurs during task performance, and, following Portolés and Martí (2017), this is an issue that may be explored in future studies. In fact, in spite of the school claiming to foster multilingual education, both in FL and CLIL classrooms a monolingual approach towards language teaching and learning is observed. This also suggests the need to train teachers in multilingual pedagogies (Portolés \& Martí, 2018; Safont, 2017), pointing out the benefits of using different languages in the classroom.

Despite the limitations, the present study contributes to our understanding on the use of the principles of CLT in FL and CLIL learning environments. It responds to a research gap regarding the need for classroom based studies which explore the implementation of CLT across different language learning contexts. In particular, it 
provides information on the impact of communicative language teaching in primary education, both in FL and CLIL classrooms.

Finally, it is worth pointing out some pedagogical implications that our findings suggest. First, in content based instruction, both in whole group and peer group task performance, teachers need to find strategies to draw attention both to language and content. Secondly, teacher-training courses should encourage language and content teachers to explore the impact of corrective- vs. communicative-oriented approaches to learning language and content. Finally, it is important to encourage teachers to carry out action research projects to explore the reasons underlying the differences in collaborative work, use of L1 and L2, and provision of feedback during task performance in different FL and CLIL settings.

\section{References}

Alcón-Soler, E. (2018). Effects of task supported language teaching on learners' use and knowledge of email request mitigators. In N. Taguchi, \& Y. Kim (Eds.), Task-Based Language Teaching (Vol. 10, pp. 56-81). Amsterdam: John Benjamins Publishing Company.

Alcón-Soler, E., \& García-Mayo, M. P. (2008). Focus on form and learning outcomes in the foreign language classroom. In J. Philip, R. Oliver, \& A. Mackey (Eds.), Child's Play? Second Language Acquisition and the Younger Learner (pp. 173-192). Amsterdam: John Benjamins. https://doi.org/10.1075/1llt.23.12sol

Brandl, K. (2008). Communicative Language Teaching in Action: Putting Principles to Work. Washington: Pearson.

Cenoz, J. (2013). Defining Multilingualism. Annual Review of Applied Linguistics, 33, 3-18. https://doi.org/10.1 017/S026719051300007X

Cenoz, J., Genesee, F., \& Gorter, D. (2014). Critical Analysis of CLIL: Taking Stock and Looking Forward. Applied Linguistics, 35(3), 243-262. https://doi.org/10.1093/applin/amt011

Dalton-Puffer, C. (2007). Discourse in Content and Language Integrated Learning (CLIL) Classrooms (Vol. 20). Amsterdam: John Benjamins. https://doi.org/10.1075/11lt.20

Ellis, R. (2003). Task-based language learning and teaching. Oxford: Oxford University Press.

Ellis, R. (2009). Task-based language teaching: sorting out the misunderstandings. International Journal of Applied Linguistics, 19, 221-246. https://doi.org/10.1111/j.1473-4192.2009.00231.x

Ellis, R., Basturkmen, H., \& Loewen, S. (2001). Preemptive focus on form in the ESL classroom. TESOL Quarterly, 35(3), 407-432. https://doi.org/10.2307/3588029

Ellis, R., \& Shintani, N. (Eds.) (2013). Exploring Language Pedagogy through Second Language Acquisition Research. Abingdon: Routledge. https://doi.org/10.4324/9780203796580

García-Mayo, M. P., \& Alcón-Soler, E. (2013). Input, output. The interactionist framework. In J. Herschensohn, \& M. Young-Scholten (Eds.), The handbook of second language acquisition (pp. 209-229). Cambridge: Cambridge University Press. https://doi.org/10.1017/CBO9781139051729.014

García-Mayo, M. P. (Ed.) (2015). The interface between task-based language teaching and content-based instruction, System, 54, 1-3. https://doi.org/10.1016/j.system.2015.09.003

Howatt, A. P. R (1984). A History of English Language Teaching. Oxford: Oxford University Press. https://doi.org/10.1093/elt/38.4.300

Krashen, S. (1981). Second Language Acquisition and Second language learning. Oxford: Pergamon.

Jessner, U. (2008). A DST Model of Multilingualism and the Role of Metalinguistic Awareness. The Modern Language Journal, 92(2), 270-283. https://doi.org/10.1111/j.1540-4781.2008.00718.x

Lantolf, J. P. (2000). Sociocultural theory and second language learning. Oxford: Oxford University Press.

Llinares, A., \& Morton, T. (Eds.). (2017). Applied Linguistics Perspectives on CLIL (Vol. 47). Amsterdam: John Benjamins. https://doi.org/10.1075/11t.47

Long, M.H. (1996). The role of the linguistic environment in second language acquisition. In W. Ritchie, \& C. T. K. Bathia (Eds.), Handbook of Second Language Acquisition (pp. 413-468). San Diego: Academic Press.

Lyster, R. (1998). Recasts, Repetition, and Ambiguity in L2 Classroom Discourse. Studies in Second Language Acquisition, 20(1), 51-8. https://doi.org/10.1017/S027226319800103X

Lyster, R., \& Mori, H. (2006). Interactional Feedback and Instructional Counterbalance. Studies in Second 
Language Acquisition, 28(2). https://doi.org/10.1017/S0272263106060128

Lyster, R., \& Saito, K. (2010). Oral Feedback in Classroom Sla. Studies in Second Language Acquisition, 32(02), 265-302. https://doi.org/10.1017/S0272263109990520

Mackey, A. (2006). Feedback, noticing and instructed second language learning. Applied Linguistics, 27, 405-430. https://doi.org/10.1093/applin/ami051

Mackey, A. (2007). Conversational interaction in second language acquisition. Oxford: Oxford University Press.

Mehisto P., Frigols, M. J., \& Marsh, D. (2008). Uncovering CLIL: Content and Language Integrated Learning and Multilingual Education. Oxford: United Kingdom.

Pica, T. (1994). Research on Negotiation: What Does It Reveal About Second-Language Learning Conditions, Processes, and Outcomes? Language Learning, 44(3), 493-527. https://doi.org/10.1111/j.1467-1770.1994.tb 01115.x

Portolés, L. \& Martí, O. (2017). Translanguaging as a teaching resource in early language learning of English as an additional language (EAL). Bellaterra Journal of Teaching, Learning Language \& Literature, 10, 61-77. https://doi.org/10.5565/rev/jt13.698

Portolés, L., \& Martí, O. (2018). Teachers' beliefs about multilingual pedagogies and the role of initial training. International Journal of Multilingualism, 1-17. https://doi.org/10.1080/14790718.2018.1515206

Richards, J. C., \& Nunan, D. (1990). Second language teacher education. Cambridge: Cambridge University Press.

Richards, J. C., \& Rodgers, T. (1986). Approaches and Methods in Language Teaching. Cambridge: Cambridge University Press.

Ruiz de Zarobe, Y., \& Jiménez Catalán, R. M. (2009). Content and language integrated learning: evidence from research in Europe. Clevedon: Multilingual Matters. https://doi.org/10.21832/9781847691675

Ruiz de Zarobe, Y. (2013). CLIL implementation: From policy-makers to individual initiatives. International Journal of Bilingual Education and Bilingualism, 16(3), 231-243. https://doi.org/10.1080/13670050.2 013.777383

Ruiz de Zarobe, Y. (2015). The Effects of Implementing CLIL in Education. In M. Juan-Garau, \& J. Salazar-Noguera (Eds.), Content-based Language Learning in Multilingual Educational Environments (Vol. 23, pp. 51-68). Cham: Springer. https://doi.org/10.1007/978-3-319-11496-5_4

Safont, P. (2017). Third language acquisition in multilingual contexts. In J. Cenoz, D. Gorter, \& M. Stephen, (Eds.), Language awareness and multilingualism (pp. 137-148). Switzerland: Springer.

Sánchez, A. (1997). Los Métodos en la enseñanza de idiomas. Evolución histórica y análisis didáctico. Madrid: SEGL.

Skehan, P. (1996). A framework for the implementation of task-based instruction, Applied Linguistics, 17, 38-62. https://doi.org/10.1093/applin/17.1.38

Vygotsky, L. (1978). Mind in society. Cambridge, MA: MIT Press.

\section{Appendices}

Appendix A. Observation Scheme1: Principles of Communicative Language Teaching (CLT)

CLT Principals for FL and CLIL sessions

Principle 1: Use tasks as an organizational principle.

Principle 2: Promote learning by doing

Principle 3: Input needs to be rich.

Principle 4: Input needs to be meaningful, comprehensible, and elaborated

Principle 5: Promote cooperative and collaborative learning

Principle 6: Focus on form

Principle 7: Provide error corrective feedback 
Appendix B. Observation scheme 2: Peer interaction in FL and CLIL sessions

\begin{tabular}{lll}
\hline Items observed & CLIL & $F L$
\end{tabular}

Learners' collaborative work

Focus on meaning

Focus on form

Use of L1

Use of L2

Assist each other with feedback

Appendix C. Observation Scheme 3: Teacher-students interaction in FL and CLIL sessions

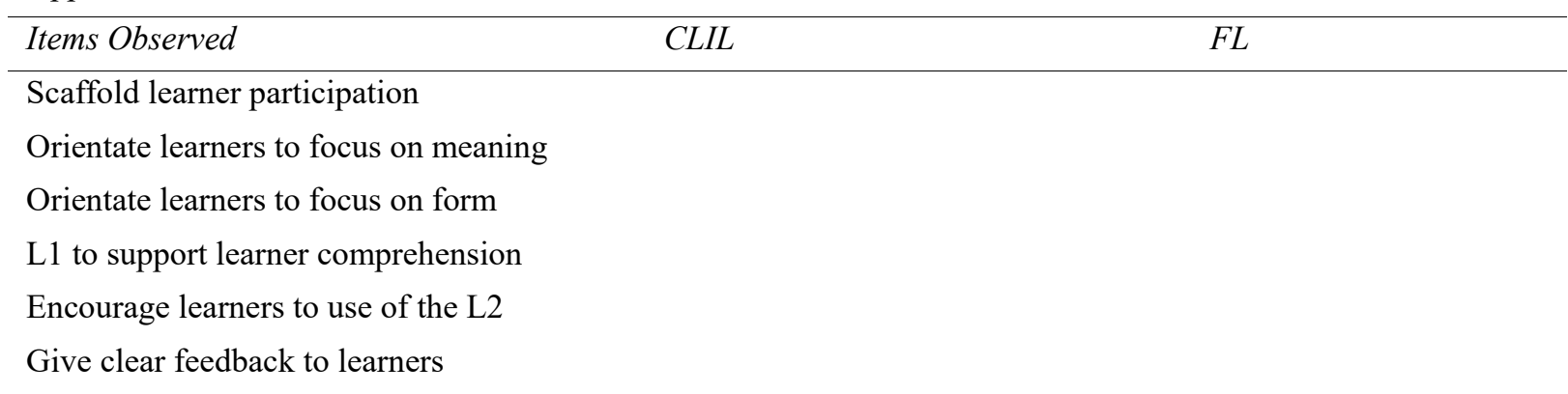

\section{Copyrights}

Copyright for this article is retained by the author(s), with first publication rights granted to the journal.

This is an open-access article distributed under the terms and conditions of the Creative Commons Attribution license (http://creativecommons.org/licenses/by/4.0/). 